\title{
THE EFFECTIVENESS OF PICTURE CHART MEDIA ON STUDENTS' ENGLISH VOCABULARY
}

\author{
Novanie Sulastri \\ STAIN Palangka Raya \\ novanie.sulastri@yahoo.com
}

\begin{abstract}
The study is aimed at investigating the effectiveness of using picture chart media on students' English vocabulary. The study belonged to pre-experimental study by applying counterbalance procedure to collect the data. The study was conducted at the class VII-5 at the SMPN 1 Palangka Raya. The number of the sample was 40 students. This study was restricted to focus on teaching vocabulary especially in classification of vocabulary. To answer the research problem, the $t$ test for correlated was applied. The research findings showed that teaching vocabulary by using picture chart media gives effect toward the seventh grade students' English vocabulary. The mean score of posttest reached higher score than the mean score of pretest $(X=57.105<Y=84.79)$. Meanwhile, $t$ test formula using manual calculation showed that the $t$ observed was 15.036. By comparing the $t$ observed with the $t$ table, it was found that the $t$ observed was higher than $t$ table at $5 \%$ level significance or $\mathrm{t}$ observed $=15.036>\mathrm{t}$ table $=2.021$.
\end{abstract}

Keywords: picture chart media, effectiveness, English vocabulary

English is learned in Indonesia as the first foreign language. Learning English is not easy. There are four skills must be mastered by the learners especially for students. That are reading, listening, writing and reading. Beside those four skills, they have to learn English grammar, spelling, vocabulary, and pronunciation that are taught to support development of the four language skills. Therefore, vocabulary is one of the important language elements the students should master.

Vocabulary includes collections of words. The words are known not only as individual words, but also as a group of words that have meaning. Mastering vocabulary is important for learners since vocabulary knowledge, as one of the basic components plays an important role among the four language skills. It gives contribution to learners to perform their skills better. It is impossible for the students to perform their English appropriately, if their vocabulary is very poor.

In teaching learning process, the teacher should be able to make a good situation for easy learning in classroom. Teacher should find the best or the effective technique teaches English vocabulary. Media is a tool using by someone that help her/him easy to describing something for other people. Media as teaching aids are needed to help the student's understanding and to increase the effectiveness in the communication between teacher and 
students in the teaching and learning process. It is also used to stimulate the students' motivation and student's interest to the lesson.

Sadiman (1996:6) stated that "Media are everything that used to transfer message from the senders to the receivers in order to stimulate the student's thought, feeling, attention and interest, in such away, so that the process of learning happen."

One of the main functions of the teaching media is the teaching aid that will influence the climate, the condition and the environment of learning organized and created by the teacher (Arsyad, 2000:15). We using it must suitable with the place, situation, and condition at the time. In order to, we should be chosen what media will be use. One of media be able to use is picture. As media, picture has many useful if using in teaching learning process. In study English, picture helps the students in understanding the lesson. One of the lessons is vocabulary. Vocabulary is list of words.

The students' ability in English will be supported by the students' mastery of vocabulary. Such as speaking, reading, writing and listening. Vocabulary mastery helps English teachers to learn English easily. Like in Junior High School, students are asked to comprehend some English text. It needs mastering of vocabulary. Because of that, the writer is very interesting to make a research to know how their vocabulary mastery is. Further, one technique used by English teacher in Junior High School is using picture media.

Based on pre-observation that have been done by the writer, the writer got some information about how learning English in SMPN 1 Palangka Raya, especially at the seventh year students. In English, we know there is a lesson about vocabulary that is learns about list of words in English. The mastery of vocabulary is needed by reading, speaking, listening and writing. In reading, for instance, the students will get difficulties in comprehending the text if they do not know the words in the text. Similarly in speaking, they will have the same problem if they have only few vocabularies. In short, by having too limited vocabulary, the students will get some difficulties to master language skills, since a good store of words is crucial for understanding and communicating.

Therefore, vocabulary mastery must be on the first priority in English language teaching. In SMPN 1 Palangka Raya, some of teachers used pictures as one of teaching media. SMPN 1 Palangka Raya is one of the favorite schools in Palangka Raya, but from the information obtained, there were still many students who got less well score in English lessons. For example, students in one of class, there were 16 students from 42 students who got score less than 70 . It means that there was a problem which becomes a constraint for students in learning English.

Therefore, the writer was interested in finding out how the actual function of media in giving effect to the students to facilitate students in understanding the lessons, especially English vocabulary.

Based on the background of the study above, the problems of the study is then stated, "Do the students of the class VII-5 at SMPN 1 Palangka Raya taught by using picture chart media gain better 
scores in vocabulary than those taught by non-picture media?"

The study is only conducted to the VII-5 students at SMPN 1 Palangka Raya in Academic Year 2010/2011 because this class has lower score in English compared other class. This study is also limited on teaching vocabulary especially in classification of vocabulary.

This study is expected to have theoritical and practical contribution. Theoretically, it is to show that this study support the theories of media in helping teaching learning process. Practically, it is expected to give contribution to the English teachers to solve the students' difficulty in learning vocabulary. For the students, by learning vocabulary using media will provide motivation and support so that students can learn easily and increase their ability in English vocabulary.

\section{METHOD}

Pre-experimental research design was applied in this current study by utilizing one-group pre-test/post-test design. It is one of the most frequently used designs in education (Toendan, 20006:236).

In this experiment, the writer taught the students directly. Firstly, the writer gave pretest to students in order to measure the students' mastery in mastery vocabulary especially about noun before using picture chart media. Secondly, the writer taught the students for four times by using picture chart media. Nouns were discussed in each meeting in different topic. Third, there was posttest in order to measure the students' mastery after treatment.
The process of teaching learning was started from 18 October 2010 until 1 December 2010. In other words, there are four times for doing treatment. Meanwhile, Pretest was done in the first meeting or before treatment and Posttest was done in the last meeting or after the treatment. Therefore, the total meeting was six times.

The researcher only chooses one class which was related to this study by using purposive sampling. In this case, the sample of this study is all the VII-5 students at SMPN 1 Palangkaraya. The numbers of students are about 38 students.

To collect the data, the researcher gave some test for the students about English vocabulary. In this case, pretest used to describe the students' mastery in English vocabulary before conducting treatment and posttest used to describe the students' mastery in English vocabulary after conducting treatment. The procedure to collect the data was described as the following steps. After observed the class, the researcher determined the class into try out class and experiment class. Classify the data by giving identity $\mathrm{A}$ and $\mathrm{B}$ are the codes for each try out and experimental class. After giving codes to each result of the test, the writer gave scoring based on the formulation. Finally, the writer classified the students' score by using the evaluation standards of English subject to know that they pass or fail. The last process, the data inserted to a certain table and arrange the numbering then calculated them.

To answer the research problem, it would be analyzed the data using $t$ test for correlated samples. It was used to find out 
the comparison of using picture chart and without using picture chart.

\section{FINDINGS}

The findings of the students' vocabulary without using picture chart were obtained. The test was done in October 18, 2010. In this case, the sample of this study is all the VII-5 students at SMPN 1 Palangkaraya. The numbers of students are about 38 students.

From the results of the pretest, it can be seen from Figure 1 about the students' pretest score. There was one student who got score 30 . There was one student who got score 35. There were four students who got score 40. There were four students who got score 45 . There were three students who got score 50. There were four students who got 55 . There were seven students who got 60 . There were six students who got 65 . There were four students who got 70 . There were three students who got 75 . And there was one student who got score 80 . In this case, many students got score under 70 .

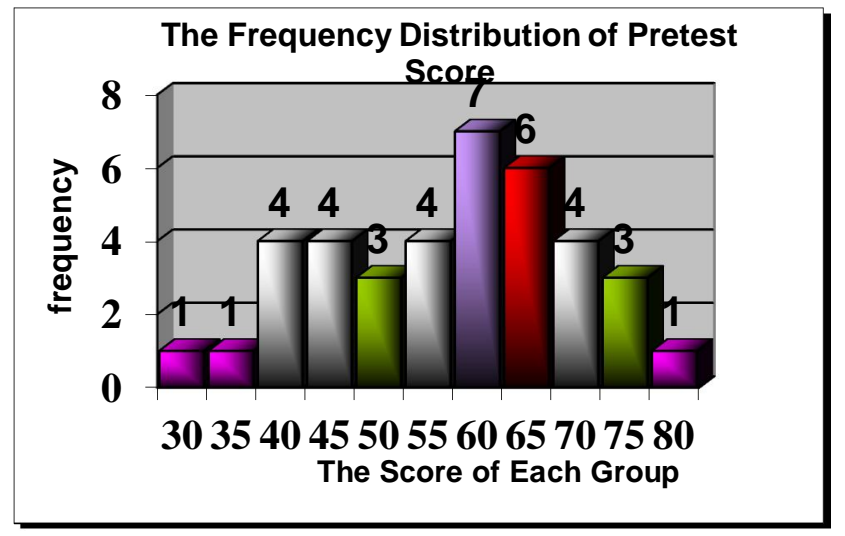

Figure 1. The Frequency Distribution of Pretest Score
Meanwhile, the findings of the students' vocabulary using picture chart were gotten. The test was done in December 1, 2010, with the same variable. Based on the output, it was found that there was one student who got score 55 . There were two students who got score 60 . There were four students who got score 65 . There was one student who got score 70. There were three students who got score 75 . There were two students who got 80 . There were eight students who got 85 . There were five students who got 90 . There were five students who got 95 . There were seven students who got 100 . In this case, many students got score up to 70.

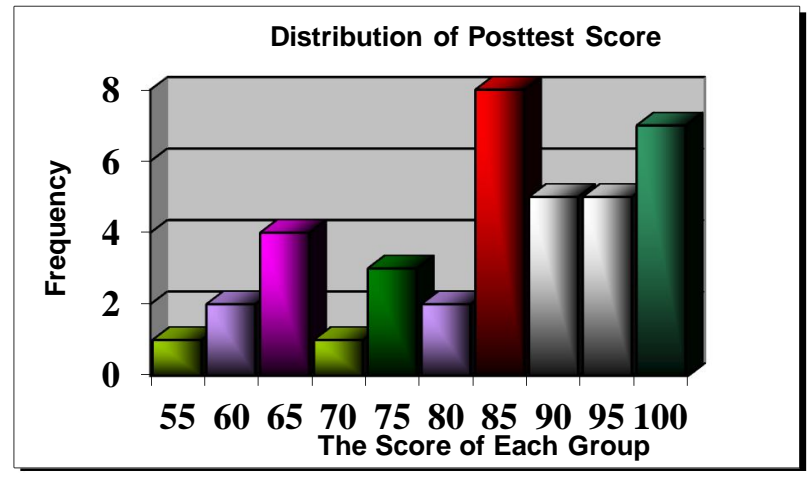

Figure 2. The Frequency Distribution of Posttest Score

Then the researcher tested the Statistical Hypothesis using $t$ test for correlated samples, as described in Table 1. 
Table 1. The Result of T-test

\begin{tabular}{cccccc}
\hline $\mathbf{M D}_{\mathbf{D}}$ & $\mathbf{S D}_{\mathbf{D}}$ & $\mathbf{S E}_{\mathrm{MD}}$ & $\boldsymbol{t}_{\mathbf{o}}$ & $\boldsymbol{t}_{\mathbf{t}} \mathbf{5 \%}$ & $\mathbf{D f}$ \\
\hline 26.974 & 10.915 & 1.794 & 15.036 & 2.021 & 37 \\
\hline
\end{tabular}

From the data above, it can be known that teaching vocabulary by using picture as the media of learning process give significant effects in improving students' English vocabulary.

To answer the research problem, whether there was a significant difference between without using picture chart and using chart, the $t$ tedt for correlated samples was applied. It was applied to see the significant difference between both of them.

The result of data analysis showed that teaching vocabulary by using Picture Media gives effect toward the Seventh grade students. It can be seen first from the means score between Pretest and Posttest. The mean score of Posttest reached higher score than the mean score of Pretest $(X=57.105<Y=84.079)$. It indicated that the students' score increased after conducting treatment. In other words, teaching vocabulary by using picture media gave significant effect toward the students' vocabulary.

Meanwhile, after the data was calculated using the test formula using manual calculation showed that the tobserved was 15.036 . By comparing the tobserved with the table, it was found that the tobserved was higher than table at $5 \%$ level significance or tobserved $=15.036>$ table $=2.021$.

The results supported by theory of Sudjana \& Rivai (2002:36) about the reasons why teaching media could increase students' learning process. The first reason is about the advantage of media in learning process, such as: teaching process will be more interesting; the materials clearly in meaning; the teaching method will be more varieties, not only verbal communication by the teacher; students will do more learning activity, because not only listen the teacher's explanation but also other activity like observe, make something, demonstration, etc. The second reasons is about how the level of student thinking. Level of human thinking is follow the developments of human begin from the concrete to the abstract, from the simple thinking to the complex. By teaching media make the abstract thing to be concrete and make the complex thing to be simple.

\section{DISCUSSION}

Dealing with the research findings stating that there was a very significant difference between improving the student's English vocabulary using picture chart media and improving the student's English vocabulary without using picture chart media, there were possibly due to a number of arguments.

First, the subjects of the study were students of SMPN 1 Palangka Raya who were taking English course. In this course, the subjects studied English vocabulary especially about noun. Shoebottom (2011:96) said that learning vocabulary is a very important part of learning a language. The more words you know, the more you will be able to understand what you hear and read; and the better you will be able to say what you want to when speaking or writing. Here are some suggestions to decide which ones to 
concentrate on: learn the words that are important to the subjects you are studying, learn the words that you read or hear again and again, learn the words that you know you will often want to use yourself, do not learn words that are rare or not useful. They did lots of exercise in improving English vocabulary by using the picture chart media. This indicated a tendency that the subjects got more experience in improving English vocabulary by using the picture chart media and was familiar with it. This possibly made that improving English vocabulary by using the picture chart media was much better than writing without using it.

Second, Sadiman (1996:6) said that media are everything that used to transfer message from the senders to the receivers in order to stimulate the student's thought, feeling, attention and interest, in such away, so that the process of learning happen. One of the main functions of the teaching media is the teaching aid that will influence the climate, the condition and the environment of learning organized and created by the teacher (Arsyad, 2000:15). Improving English vocabulary by using picture chart media was useful not only for students' improvement, but also to attract students' interest in learning English specifically for enriching their English vocabulary ability. Picture is a visual media in the form of scratches or other forms which can bring about responses, perception, or human ideas toward an object or other things. There are many kinds of picture which can be used as teaching and learning media. Every picture kind has different excess and flaws each other. There are some kinds of picture which is able to use as teaching and learning media, such as: stick figure, sketch, illustration, photo, poster, flash card, folder, cartoon, and caricature (Fauziati, 2002:176-177).

Third, the students' ability in English will be supported by the students' mastery of vocabulary. Such as speaking, reading, writing and listening. Vocabulary mastery helps English teachers to learn English easily. Like in Junior High School, students are asked to comprehend some English text. It needs mastering of vocabulary. Because of that, the writer is very interesting to make a research to know how their vocabulary mastery is. Further, one technique used by English teacher in Junior High School is using picture media.

Based on pre-observation that have been done by the writer, the writer got some information about how learning English in SMPN 1 Palangka Raya, especially at the seventh year students. In English, we know there is a lesson about vocabulary that is learns about list of words in English. The mastery of vocabulary is needed by reading, speaking, listening and writing. In reading, for instance, the students will get difficulties in comprehending the text if they do not know the words in the text. Similarly in speaking, they will have the same problem if they have only few vocabularies. In short, by having too limited vocabulary, the students will get some difficulties to master language skills, since a good store of words is crucial for understanding and communicating. Therefore, vocabulary mastery must be on the first priority in English language teaching. In SMPN 1 Palangka Raya, some of teachers used pictures as one of teaching media. SMPN 1 Palangka Raya is 
one of the favorite schools in Palangka Raya, but from the information obtained, there were still many students who got less well score in English lessons. For example, students in one of class, there were 16 students from 42 students who got score less than 70. It was compatible with concept of learning English by using fun material and fun activity. The atmosphere of class would be relaxed and more conducive so that students were easiest to get understanding and also improving their English ability. Based on the finding of this study, it could be concluded that improving the students' vocabulary by using picture chart media was much better than those without using picture chart media.

\section{CONCLUSION}

Based on the result of data analysis from vocabulary scores which gained by students before and after conducting treatment, there were significantly different $\left(t_{\text {observed }}=15.036>t_{\text {table }}=2.021\right.$ at $5 \%$ level of significance. This indicated that teaching vocabulary by using picture media gives significant effect toward the students' vocabulary. It implicated, if the students were taught vocabulary by using picture media therefore, the students' vocabulary score would be higher than without using picture media. On the contrary, if the students were taught vocabulary without using picture media, the students' score of vocabulary would be lower than the use of picture media. It can be proved by the difference of Pretest and Posttest score.
Based on the evaluation standard of English subject, it can be concluded that the students pass the test if they get score seventy or more indicating that the students master the material. Meanwhile, the students do not pass the test if they get score under seventy which indicate that they still do not master the material. Since the mean score of posttest was 84.079, the students of class VII-5 at SMPN-1 Palangka Raya still did not master in vocabulary. However, there were only seven students who still got score below the standard and other obtained improvement in their scores.

In line with the conclusion, the writer would like to propose the following suggestions that hopefully would be great to use for the seventh grade students at SMPN 1 Palangka Raya, the teachers there and the researcher. It is recommended for the students to pay attention to the lesson because the learning becomes more interesting, interactive and the students' role to be more positive. By learning vocabulary using media will provide motivation and support so that students can learn easily and increase their ability in English vocabulary. Then the English teachers are recommended to use picture chart media in teaching vocabulary to motivate the students, to improve their students' vocabulary in English. Finally, further research can improve the study with the better design in order to support the result finding by implementing a new one in order to give more improvement to the students' score and more understanding in vocabulary. 


\section{REFERENCES}

Arsyad, A. (2000). Media pengajaran. Jakarta: Raja Grafindo Persada.

Fauziati, E. (2002). Teaching English as a foreign language. Surakarta: Muhammadiyah Press.

Sadiman, A. S. (1996). Media pendidikan (pengertian, pengembangan, dan pemanfaatannya). Jakarta: Raja Grafindo Persada.
Shoebottom, P. (2011). How to learn vocabulary. (Online). Retrieved from http://esl.fis.edu/learners/advice/ vocab. html.)

Sudjana, N. \& Rivai, A. (2002). Media pengajaran. Bandung: Sinar Baru Algensindo.

Toendan, W. (2006). Educational research methods: An introduction. Palangka Raya: University of Palangka Raya. 